\title{
ANALYSIS OF INSTITUTIONAL RISKS OF SUSTAINABLE SEA DEVELOPMENT IN UKRAINE
}

\author{
Natalya Andryeyeva ${ }^{1}$ \\ Institute of Market Problems and Economic \& Ecological Studies \\ of National Academy of Sciences of Ukraine, Ukraine \\ Volodymyr Hotsuliak ${ }^{2}$ \\ Kyiv National University of Trade and Economics, Ukraine \\ Stanislav Gorbachenko ${ }^{3}$ \\ Odessa I.I. Mechnikov National University, Ukraine
}

\begin{abstract}
The research objective is to define institutional risks in the process of formation of the institutional environment of the maritime economy sphere within the context of the implementation of international sustainable development policy into Ukrainian economy. The article considers the risks and threats of the emergence of institutional risks and "traps" in the economy, their influence on maintaining sustainable development of the maritime economic sphere in Ukraine. The article analyses peculiarities and causes of the crisis situations of 20132017 in the Ukrainian maritime economy, discovers the existing structural imbalance of institutional environment and offers a set of measures for the integration of national objects of the maritime economy into European maritime clusters. Methodology. The research defines the essence and interrelation of institutional risks and institutional "traps" in the modern institutional theory. It was established that institutional "traps" in the maritime economy emerge due to management misjudgements in relation to new regulations suggested by policymakers and inefficient institutions without taking into account the existing economic and environmental risks for economic activities at the microeconomic level. That is to say when the state ignores the main institutional threats: resilience of shadow arrangements; a procedural overload of the management system; immaturity of the regulatory-legislative sphere, resource-intensiveness of organisations and their interrelations. Practical implications. The conducted research on the existing institutional risks (traps) of the Ukrainian maritime economy allowed discovering the level of structural deformations of the institutional environment in accordance with sustainable development methodology, to offer an action plan for improving the institutional environment that would allow removing the existing social, economic and environmental risks. Value/originality. The article demonstrates that though institutional risks are of common nature for various countries and scopes of activity, they do not work in the same way and have different symptoms of emergence in each separate sphere, in particular, in maritime economy. Thus, the recommendations for their prevention and overcoming substantially differ from each other. The research offers a set of priority tasks for overcoming the crisis phenomena in the sphere of the maritime economy of the Ukrainian Black-Sea region related to the transition of Ukrainian business structures to sustainable development. The authors have determined that institutional risks that influence various segments of economic activities are complex in nature. In this context, determination of interrelations between institutional risks and other types of risks, in particular, economic and environmental ones, becomes especially important.
\end{abstract}

Key words: institutional risks and "traps", sustainable development, maritime economic sphere, Ukrainian Black Sea region.

JEL Classification: B52, O44, Q01, R49

\footnotetext{
Corresponding author:

${ }^{1}$ Department of Economic and Environmental Problems of Seaside Regions, Institute of Market Problems and Economic \& Ecological

Studies of National Academy of Sciences of Ukraine.

E-mail: andreevann@ukr.net

${ }^{2}$ Department of Financial Analysis and Audit, Kyiv National University of Trade and Economics.

E-mail:vgotsuliak@ukr.net

${ }^{3}$ Department of Economics and Management, Odessa I.I. Mechnikov National University.

E-mail: stas_gorbachenko@ukr.net
} 


\section{Introduction}

Relevance of research works on institutional risks of sustainable development of the Ukrainian Black Sea region's maritime economic sphere is conditioned by the lack of regulation of strategic development priorities, low level of environmentalization of economic activities virtually in all the production domains, increasing degradation of the natural and resource potential, and exacerbation of economic, social, and environmental situation essentially in all regions of Ukraine.

In Ukraine, in the current conditions, a special place should be given to the institutional policy of establishing it as an economically independent (sovereign) maritime state. At the same time, it is necessary to clearly understand that, firstly, the role of the maritime factor will be growing each year for Ukraine and will play a landmark role in the future; secondly, establishment of Ukraine as a maritime state is, first of all, closely related to the development of port industrial areas. We deem it necessary to underscore that the state interests of Ukraine and global community related to sustainable development of maritime economic sphere are determined by the geoeconomic and geostrategic importance of using the Black Sea for transportation and reclamation of its resource potential. In general, the state interests of Ukraine in the maritime domain constitute a total of economic, social, political, environmental and other interests of the state. But it is due to the uncertainty of the institutional reforms in accordance with the world standards that the further balanced development of the maritime economic sphere is slowed down. This article determines the essence of institutional risks, demonstrates interrelations between institutional risks and institutional "traps"; provides research on separate most topical and problematic aspects of formation of the institutional environment related to ensuring economic and environmental interests of Ukraine within the context of sustainable development of the management systems for objects of functioning of the Ukrainian Black Sea region's coastal zone.

Analysis of research works and publications. Determining institutional risks (traps) and improvement of the institutional environment of the maritime economy sphere in Ukraine in accordance with the international paradigm of sustainable development and the best world practices is a new problem both for the economy of Ukraine and for the entire international community, which tends to become very topical in the nearest future. The analysis of general approaches to the formation of state institutional policy, social and economic situation, problematic environmental issues of sustainable development of the maritime economic sphere of the Ukrainian Black Sea region have motivated Ukrainian researchers for intensive and deep study of the phenomenon of formation of the new institutional foundation related to overcoming the current economic and environmental imbalance and discovery of crisis phenomena in the formation of the state maritime policy.

Issues of the creation of rules and regulations for the functioning of societies have been considered by a large number of renowned scientists, analysts, and practitioners of institutional theory, state governance, and other directions of economic or social sciences. Thus, J. Brennan and J. Buchanan (2005), E. Ostrom (1990), J. Mokyr (2002) favour the social nature of their emergence. In the works of P. Knopfel, S. Varon, N. Malysheva (2010), T. Eggertsonn (2005), V. Lowndes (1996), there can be traced an inclination towards the consideration of this range of problems from the point of view of political variations. R. Coase (2007), D. North $(1997,2010)$, E. Furubotn and R. Richter (1991) tend to see the transformation of economic environment as the reason for changes of institutions. Gradstein (2008) pays a special attention in his research to determining the interrelation between institutional "traps" and economic growth. However, as a rule, the points of view of each author complement each other when it comes to the causes of the emergence of institutional risks or "traps" in the public sphere. Unfortunately, examination of most of the studies allows emphasizing that institutional risks are usually considered only through the social and economics lens. At the same time, most of the scientific articles do not pay any attention to the environmental aspect of studies. The modern approach to the international sustainable development paradigm provides for comprehensive social, environmental, and economic consideration of the existing transformational issues of formation of the institutional infrastructure of the economy.

A number of Ukrainian scholars have made their contribution to the research to determine the mechanisms and tools related to institutional support of sustainable development of the maritime economic activities of the objects of Ukrainian Black Sea region, in particular: R. Kryzhanovskyi (1991), O. Hromova (2001), B. Burkynskyi and V. Stepanov (2008), A. Fylypenko, V. Baryshnikova (2013), and others. The applied task of the research is the discovery of problems and assessment of crisis situation related to the formation of new institutes in economic and environmental spheres of the objects of maritime economic activities of the Ukrainian Black Sea region, as well as the development of offers to improve the institutional environment.

\section{The methodology of implementation of the theory of institutional risks in the maritime economic sphere of Ukraine}

Institutional aspects of development are currently acquiring a special importance. In the presentday conditions, ignoring an institutional crisis or attempting to tackle it with typical measures aimed 
at overcoming local issues (for instance, financial and economic or economic and environmental crisis) using examples of developed countries, where institutional crisis is absent or far less evident, leads to its conservation or growth, which would permanently reduce the efficiency and management capabilities of public administration, as well as efficiency and competitiveness of national economy. A special group of institutional risks is constituted by the risks arising out of the unconcerted behaviour of the state in the economic and environmental management sphere. All of this can lead to growing social tensions and risks of emergence of civil unrest. As a result, the economy of Ukraine is deprived of efficient possibilities of growth, and the country's political structure is isolating itself in the system of unresolved issues of its own economic and environmental efficiency of sustainable development, which reduces the country's competitiveness and bears unforeseen consequences for the functioning of the state organism. Thus, the issues of investigating the risks of activation of institutional "traps" arise on a new scale, for these traps can potentially cause emergence of new shadow arrangements in the country's economy (corruption, large-scale cases of monopolistic collusion on the markets, latent lobbying of individual interests etc.) alongside the new conditions of functioning of the society and state. Overcoming such risks requires a nonlinear response to the emerging social, economic and environmental challenges by way of changing the quality of institutions and institutes, i.e. realization of efficient institutional transformations.

The interdisciplinary approach to studying risk allows considering risk in the context of institutional analysis. Scientific and analytical literature usually defines the institutional risk as a social and economic phenomenon characterized by a possibility of the advent of an undesirable event caused by institutions of the economy.

There is a controversy in the economic science regarding the nature and conceptual framework of institutional functions and dysfunctions. The institutional theory determines that the function of coordination is expressed in the fact that awareness of a separate rule allows individuals to carry out mutually beneficial actions (Kouz, 2007). This function ensures coordination of actions of economic entities and reduces the level of uncertainty in social and economic relations. The distributive function provides for the prohibition of certain actions, the concentration of resources only with unprohibited ones or those that are directly suggested. Institutes carry out redistribution of resources, expenses, and benefits from certain economic entities to others. Informational and motivational functions of institutes are also distinguished. These functions are not universal, but their failure also leads to inefficiency of institutes.

Dysfunctions of institutes determine their inefficiency, there emerges a possibility that interests and objectives of economic entities will not be achieved, and an institutional risk comes up. Therefore, the author's understanding of the reason of emergence of institutional risks is related to the disorders in the institutes of the economy. Research of the main functions of institutes and consequences of their disorders allowed singling out the results of institutional dysfunctions: 1) institutional uncertainty; 2) institutional traps; 3) atrophy, degeneration, and extinction of an institute; 4) institutional conflict and rejection of an institute.

To sum up the above, let us specify the definition of an institutional risk as a social, economic, and environmental phenomenon that is caused by dysfunctions of institutes, which is characterized by the possibility of advent of an undesirable event for an economic entity, which hinders realization of its economic interest due to growth of transaction costs. Study of peculiarities of reformation of the maritime economic complex of Ukraine, first of all, envisages paying most of the attention to the stages of institutional uncertainty and discovery of an institutional trap. There were attempts in the world's scientific literature to research the reasons for the emergence of institutional traps.

Naturally, an institutional trap can be avoided or overcome by means of revision of formation rules for organizations' (enterprises') structure and the structure of their relations in the context of transactional and transformational expenses, as well as of the level of inefficient institutions' penetration into economic activity. Therefore, management mechanisms should be used for modelling relations between economic entities, inside them, and with government agencies by means of operating all the expenses of economic entities to carry out business activities (Weimer \& Vining, 1998).

As a result, in realistic conditions of a competitive (not necessarily a market) environment, the crucial role is played by the level of behavioural preparedness and predictability of balance of interests of direct and indirect competitors in a future system (Weimer \&Vining, 1998).

Institutional transformations emerge as a result of the development of situations of collective and constitutional choice, in particular, a situation of institutional choice (Ostrom, 1990) - achievement of political and economic consensus in the society by the entire range of interested parties. Thus, according to E. Ostrum (1990), the situations deemed as typical are those when institutional traps come into play as a result of three principal risks prevailing in the process of choice of reaction and behaviour of economic agents in the conditions of institutional transformation: total hostility; limited perspective; and unpredictable result.

The risk of total hostility. The essence of the risk can be determined in the following way: efforts to prevent the threat of "resilience of shadow arrangements" (for example, reduction of official payments, limitation of 
time frames for consideration of applications etc.), in case of preservation of the threats of "procedural overload" and "resource-intensiveness of the enterprise's organization", leave the environment without changes.

The risk of limited perspective. Efforts to remove the threat of the "resource-intensiveness of the enterprise's organization" (for example, introduction of short timeframes for procedures, guaranteeing inviolability of property, investments, contractual terms etc.), in case of preservation of the threats of "resilience of shadow arrangements" and "procedural overload", will create the conditions where each economic agent, due to the previously obtained informal connections, will be trying to use them in a most efficient way in the algorithm of passage of the procedures and, if possible, expand them, so that the removed competitive obstacles turn into fullfledged competitive advantages.

The risk of the unpredictable result. Activities of government agencies aimed at neutralization of the "procedural overload", in case of preservation of the threats of "resource-intensiveness of the enterprise's organization" and "resilience of shadow arrangements", will create a situation of confusion for market participants and government officials. Therefore, destruction of the usual algorithms of maintaining economic decisionmaking may result only in the complication of economic activities.

Informal expenses will only grow due to the necessity of establishment of new shadow arrangements; moreover, there will also be an increase in time necessary for entering the market or entering into agreements between counterparties or in unsustainable use of natural resources. For the majority of economic agents, it becomes unclear, which type of behaviour they should choose and what results they should expect (abide by new formal rules or adjust the shadow arrangements) because no result can now be achieved automatically. The agents' decisions are now more and more depending on how they would construe the contents of the new procedures, and on whether they would really abide by those procedures (Knopfel, Larue, Varon, \& Malysheva, 2010). This increases direct risks related to the achievement of the desired result for each participant and brings into question the acceptance of any new rules in a long-term perspective. As a result, there emerges an unsystematic (dispersed) resistance, which was clearly demonstrated by the attempts of implementation of reforms in the Ukrainian marine economic sphere in 2013-2017.

Therefore, an attempt to transform the institutional framework (a number of fundamental regulations) is followed by a change in the structure of stimuli for economic agents. That is to say, in the process of establishment of any reforms, in order to improve their understanding by market participants, it is necessary to be aware of the strategic consequences of a change of a specific institution on the environment of operation, and on the extension of knowledge about its potential possibilities.

Continuous accumulation of various institutional traps promotes gradual unfolding of negative phenomena in the institutional environment, which with the time becomes a cause of the emergence of an institutional crisis. It is noteworthy that as a result of the global financial and economic crisis, in Ukraine, there occurred a dramatic exacerbation of the main drawbacks of the national economy with prominent features of theretofore latent institutional crisis (Zhalilo, 2009), its overflowing from economic into social, political, and environmental domains.

\section{Institutional imbalance and risks of the policy of sustainable development of objects of Ukrainian port industrial areas}

The peculiarity of determining economic and environmental problems of development of Ukrainian maritime coastal areas is conditioned, first of all, by the reformation of the maritime economic complex and the necessity to actively use modern forms of investment into the development of port infrastructure. A seaport and industrial infrastructure within port industrial areas is a complex subsystem, which is closely related to the economic, social, and environmental subsystems of the region and is developing under the influence of the factors of external (globalization, socialization, and environmentalization of the economy, integration processes etc.) and internal environment (institutional environment of a region, its level of competitiveness etc.). Therefore, evaluation of competitiveness and efficiency of functioning of facilities of port industrial areas requires determination not only of its functional characteristics but also of its role in ensuring the quality of transportation and transshipment operations of the facilities of port industrial areas, as well as economic growth of the region.

It should be noted that during the last year, Ukraine rose from the 85th to 81st position in the rating of competitiveness (Global Competitiveness Index, GCI). One of the key criteria of the rating is an evaluation of the competitiveness of transport infrastructure. The quality of port infrastructure in Ukraine has been constantly growing in the recent years, while that of the railway one is decaying. As for the motorways, Ukraine is among the ten countries with the worst roads in the world. This is declared in the annual report of Global Competitiveness Index issued by the World Economic Forum. As for the quality of infrastructure, during the last year, Ukraine worsened its rating by three points falling from the 75th to 78 th position, its grade being 3.9 of the 7 -point scale.

As a positive aspect of development, it should be emphasized thatUkrainehasbeenincludedintoindicative maps of the European transportation network TEN-T. This means that in the nearest future, Ukraine's transport 
infrastructure should become an integral part of the EU infrastructure and develop in a harmonious accord. The Trans-European Transport Network (TEN-T) project envisages the creation of a new transportation system on the territory of the EU up to 2030 uniting 94 maritime and river ports, 38 international airports, and nearly 15 thousand kilometres of high-speed railways. There are two corridors going towards the territory of Ukraine - the Mediterranean Corridor (from the Iberian Peninsula up to Hungarian-Ukrainian border) and the Rhine-Danube Corridor (through the waterways of Main and Danube, with arms from Munich to Prague, Žilina, Kosice, and up to Ukrainian border). Analysing the state of infrastructure of the maritime economy complex, it should be noted that it is closely connected with the consideration of the development of port industrial areas.

At present, the legislative framework of Ukraine does not have an unambiguous approach to the definition of the term of the essence of port industrial areas. In the opinion of the authors, this term should be considered in two aspects. Firstly, port industrial areas is a form of territorial organization of maritime economy and neighbouring coastland, interrelated and interdependent association of maritime ports, industrial enterprises, coastal settlements, social and manufacturing infrastructure, whose location in the coastal area is caused by the usage of resources of land and sea, as well as by maintenance of environmental, social-economic, and external economic functions. Secondly, port industrial areas are cluster associations of coastland population centres, neighbouring facilities of port and industrial infrastructure operating within the limits of specific territories.

The article offers the following classification of types of activities carried out within the frameworks of the functioning of the facilities in the coastal zones, in particular:

- business operations of ports, commercial and naval transport (infrastructure of ports and facilities of port enterprises; dredging; dumping; building of hydrotechnical constructions; intermodal centres within ports, ship repair and shipbuilding facilities; navigational objects);

- geological prospecting works, drilling operations and development of raw resources deposits within the territorial waters (in particular, prospecting and extraction of oil and gas);

- fishery (operations of the fishing fleet with relevant port infrastructure, as well as fish processing enterprises; aquaculture operations: fish breeding, farming of shellfish etc.);

- business operations of portside plants belonging to other industries (metallurgical, chemical, agricultural enterprises (excluding fish processing));

- recreation and resort operations (usage of beaches and seashore areas for health improvement and recreation); laying of pipelines and communication lines.

Maritime economic activities in Ukraine are, first of all, based on the extensive infrastructure system of maritime ports. This system includes 18 maritime trade ports with 4 maritime fishing ports operating together as a complex.

Modern trends of development of objects of port industrial areas in the Ukrainian Black Sea region show positive dynamics. Thus, according to the data of the Ukrainian Sea Ports Authority, in 2017, the cargo turnover in the maritime ports of Ukraine preserved positive dynamics for the entire 12 months. From January to December of the previous year, the maritime ports of Ukraine processed 132.57 million tons of cargoes, which is $0.6 \%$ more compared to 2016 . This is indicated in the operation data of the Ukrainian Sea Ports Authority. The volume of transportation of import cargoes in 2017 rose by $29.1 \%$ year on year to 20.479 million tons, the volume of export cargoes fell by $1.7 \%$ to 98.517 million tons. Within the import structure, the largest growth (6-fold) occurred with chemical and mineral fertilizers - from 20.66 thousand tons in 2016 to 123.63 thousand tons in 2017, and oil - from 506.98 tons to 848.76 tons (by $67.4 \%$ ). Coal and ore also demonstrate a sharp rise in cargo turnover, their transshipment volumes rose by $64.2 \%$ and $15.9 \%$ compared to 2016 to 6.141 million tons and 6.491 million tons respectively.

Grain has an important share in the export cargoes turnover - almost 38 million tons, and metallurgy products - 14.91 million tons. At the same time, exports of vegetable oils rose to 5.2 million tons (19\% growth compared to 2016). The volume of transit cargo processing rose by $14 \%$ to 11.804 million tons, and the volume of container processing rose almost up to 531 thousand TEU. At that, the largest volumes of cargo were processed by the Pivdennyi Port -41.889 million tons with transshipment increasing by $6.6 \%$ compared to 2016. The Odesa Port - 24.12 million tons, Mykolaiv 23.533 million tons, and Chornomorsk - 17.633 million tons. Thus, in 2017, Ukrainian maritime ports increased cargo processing by $0.832,53$ million tons compared to 2016 (Table 1). The data analysis allows to state that Ukrainian ports mostly deal with transshipment of cargoes with essential impact on the environment, and therefore, we deem it extremely necessary to determine

Table 1

Total volumes of cargo processing in maritime ports of Ukraine in 2016-2017

\begin{tabular}{|l|c|c|c|}
\hline \multirow{2}{*}{ Indicator } & \multicolumn{3}{|c|}{ Total for maritime ports } \\
\cline { 2 - 4 } & 2016 & 2017 & $\%$ \\
\hline Total cargoes & 131745.91 & 132578.44 & 100.6 \\
\hline Liquid & 10788.58 & 11016.26 & 102.1 \\
\hline Dry-cargo, loose & 93413.41 & 95745.71 & 102.5 \\
\hline Unit load & 27543.92 & 25816.47 & 93.7 \\
\hline
\end{tabular}


institutional risks of negative impact on sustainable development of the Ukrainian maritime economy.

In addition, it is worth mentioning that recently alongside with development of ports, there has also been a dynamic growth of the port-side industry. Enterprises of oil and fat sector have recently seen the greatest development in the maritime coastal zone of the Ukrainian Black Sea region, in particular, in Odesa region. The growth in exports of sunflower oil, which in most cases is carried out through seaports, has a special meaning for the entire external trade of Ukraine. According to the State Fiscal Service of Ukraine (The State Fiscal Service of Ukraine), in 2016, over 4.8 million tons of this type of oil was shipped abroad to the total amount of $\$ 3.7$ billion, which is a $10 \%$ increase in the total volume of Ukrainian exports.

The following can be named among the most significant conflict and crisis issues constituting an institutional "trap" and slowing down sustainable development of objects of maritime coastal zones:

- imbalanced operations of separate structural elements of the maritime coastal zones' objects are conditioned by the absence of program- and goal-oriented approach to the development of ports, maritime fleet, port-side industrial and recreation facilities, as well as other objects of maritime coastal zones;

- low efficiency of the fulfilment of innovation and investment plans and development programs for maritime coastal area objects is conditioned by the inadequacy of managerial decisions regarding their implementation, especially in conditions of crises;

- low efficiency of financial and economic, commercial and operational activities, as well as measures for the provision of environmental, industry-related and new types of the safety of development of port industrial areas, is conditioned by the inadequacy of regulatory environment and organization of management of maritime economic activities.

The cause-and-effect basis of the problem of the necessity of improvement of the institutional system for managing environmentalization of port industrial areas of Ukraine is as follows:

- intensive man-made transformation of the natural and resource potential of territories and offshore zones as a result of deployment of industrial, transport, utility and other objects, including those posing threat to population and environment;

- extensive (inefficient) usage of natural resources (resource-intensive production), conditioned by the low level of technological development;

- consumer attitude towards natural resources and environmental systems, the predominance of bureaucratic and temporary interests in contrast to long-term ones;

- saturation of coastal territories of Ukraine, especially in certain regions, with environmentally dangerous facilities;
- continuous practice of evaluation of investment projects and decision-making on the deployment of dangerous business systems and facilities without a comprehensive assessment of their impact on the environment and taking into account factors and forecasts of natural and man-made risks;

- the insufficiency of regulatory framework on maritime environmental management from the point of view of both contents and structure (including the fuzzy character of obligations, authorities and responsibility of government agencies of various hierarchy levels and separate persons regarding decision-making on deployment and operation of dangerous facilities, responsive measures to situations related to resource and environmental safety);

- the inadequacy of the system of government environmental regulation, including economic instruments of maritime environmental management and environmental protection activities, mechanisms for prevention and reduction of volumes of damage, stimulation of reduction of environmental pollution and relative indicators of resource usage, mechanisms of environmental insurance, funding of environmentally beneficial investment projects;

- the inadequacy of organization of prompt response in case of resource and environmental emergencies caused by natural or human factors.

This situation is conditioned by the persistence of systemic negative trends in 2013-2017 on the governmental level in relation to the reformation of the maritime sphere in general, including the following:

1) lack of proper regulation on the issues of property rights to port complexes and coastal facilities of the port-side industry. Prevalence of state ownership due to lack of investments does not allow efficiently renewing the vessel fleet of ports and carrying out infrastructure works. The maritime industry needs reorganization of the ownership system and transfer of a certain share of port infrastructure facilities to private investors;

2) persistence of technological inferiority problems in maintenance of the principal port operations mainly due to the obsoleteness of port complex, non-compliance of the throughput capacity of Ukrainian maritime ports infrastructure with international standards;

3 ) persistence of high tariff rates on servicing container transportation in maritime ports of Ukraine;

4) uncertainty in the issues of assurance of economic and environmental safety. In particular, the port infrastructure system is lacking relevant port constructions for warehousing and processing environmentally hazardous cargoes;

5) persistence of low environmental quality of the internal transportation network, limitation of the speed of transit traffic (Fylypenko \& Baryshnikova, 2013).

Analysis of the existing practice of functioning of national maritime coastal zones shows that there is an ongoing diversification of port services going beyond 
the actual port limits (its internal and external water area) and encompassing a large number of onshore and other business operations of the transportation chain. Such factors, on the one hand, condition association of transportation process participants seeking to obtain a greater economic effect from common operations; on the other hand, they stimulate implementation of innovations in the organizational and technological process of functioning of the port economy.

At the same time, there exist a number of factors with a negative impact on the very environmental quality of service provision in the commercial maritime ports of Ukraine, and among them, the following structural institutional imbalance will be gaining particular importance:

1. The absence of a unified comprehensive environmental program of development for both maritime sector of Ukraine in general, and its separate components. In the recent years, a number of resolutions have been adopted aiming to develop the maritime industry. At the same time, the above-mentioned regulatory framework has a predominantly fragmentary nature where different regulatory documents cover only some of the industry development aspects, are not interrelated and do not take into account environmental peculiarities of regions' development.

A number of laws have been adopted in Ukraine regulating the issues of strategic priorities in the development of the innovation and investment sphere of the objects of industry and transportation of maritime coastal areas, in particular, of public-private partnership. At the same time, the national legislation still has not defined such new forms of organization of business as "cluster" in general and "environmental cluster" in particular, there is no legal regulation of types, forms, and peculiarities of creation and operation of clusters. The drafts of regulatory aspects on the formation of the bases of state policy in the sphere of clustering are still waiting for approval.

2. Different departmental affiliation of enterprises and institutions operating in the maritime industry leads to incoherent management decisions, the absence of coordination of the state environmental, as well as innovative and investment policies related to the development of maritime economic complex and optimization of its infrastructural maintenance.

State-owned seaports and shipping companies of Ukraine are subordinated to the Ministry of Infrastructure; fishing-industry and fishing ports - to the Ministry of Agricultural Policy and Food; while educational institutions training maritime industry experts are subordinated to the Ministry of Education and Science. The issue of formation of environmental policy is a priority for the Ministry of Environment and Natural Resources.

3. The absence of systemic environmental information and methodological support of economic entities whose activities are related to a maritime economic complex of the region, lack of training of highly qualified experts in environmental specialties;

4. Low level of investment into environmental innovations of the country's maritime economic complex, insufficient level of interaction of the maritime economic complex with educational and scientific institutions, wear of the principal manufacturing facilities, outdated technologies that are used for transportation and processing of cargoes determine the low environmental quality of transportation and transshipment services.

The present-day dynamic situation is conditioned by the significant renovation of science and scientific directions in the system of the interrelation of economy, society, and nature. This research is using the perspective of scientific approaches to economicenvironmental security of maritime economic industry to define the author's vision regarding the determination of problematic issues of the existing economic-environmental imbalance of development of port industrial areas of Ukraine, also, on the basis of implementation of international experience into national legislation, there were suggested recommendations regarding the improvement of environmentalization management of functioning of maritime coastal zones facilities of the Ukrainian Black Sea region by the institutional system.

It should be noted that the infrastructure of maritime ports of Ukraine should achieve a new level of development that will ensure proactive development for satisfying the needs of economy and society; will ensure improvement of the system of assurance of safety of human life and prevention of human-caused emergencies at sea and adjacent territories; will be based on the modern technologies of works performance that are safe for people and environment; will ensure equal possibilities for operation of transportation process participants of all ownership types; will allow more comprehensive use of the country's transit potential; and will promote expedited integration of Ukrainian transportation system into the international and European transportation systems. In its turn, the environmental component of the strategy of sustainable development of enterprise should determine the objectives of innovative activities of maritime commercial ports, as well as define the choice of means for their achievement and sources of those means. The priority objectives of the sustainable development strategy of port industrial areas, first of all, have to be as follows: creation of maritime environmental clusters; improvement of quality of transshipment process and port services; separation of social and environmental component of cost price of cargo transportation and port services provision; improvement of technical level and efficiency of use of the main production facilities; intensification of loading and unloading works by 
means of improvement of organization and technology of transshipment; optimization of energy use by way of introduction of energy saving technologies and usage of unconventional energy sources; assurance of safety of seafaring in the port aquatic area and its vicinity; raising efficiency of use of labour resources; assurance of environmental safety of the transshipment process.

The abovementioned problems require a search for new forms of integration of financial, industrial, and intellectual capital with the aim of development of material environmental and competitive advantages of the functioning of the Ukrainian maritime economic complex. The international practice shows that clusters presupposing informal voluntary association of enterprises and organizations (producing goods and services and operating on a certain territory) have a great potential in relation to raising the competitiveness of national economic entities on both internal and external markets. The principal objectives of the cluster include optimization of the process of use of the region's and industry's available economic potential. A case in point of cluster development is the European Union countries where clusters in the marine sphere have been in existence for many years. In November 2005, the European Network of Maritime Clusters (ENMC) was created in Paris.

The European Network of Maritime Clusters is a confederation of Clusters or equivalent structures. It has to be understood as a best practices dissemination and exchange platform through the website, informal talks, and an annual summit during which each country gives a brief presentation of the economic situation of its maritime sector and the recent actions of its national organization. The aim is to establish a framework for future common targeted actions.

All of the member organizations are, or tend to be, cross-industry organizations gathering all or a part of the maritime subsectors of their countries. The type of each national Cluster varies, with some being almost state-controlled or purely private-owned or being an intermediate mix. Some Clusters include inland navigation and or logistics sectors, port industries, coastal tourism, insurance, and finance in their scope; others do not (ENMC website).

At present, clusters as a form of organization of interaction between different sectors of maritime industry are becoming more and more wide-spread. But, unfortunately, environmental infrastructural elements and objectives are absent in the philosophy of formation of international maritime clusters. Therefore, with the aim of implementation of the sustainable development paradigm into maritime economic activity in general and industrial port operations in particular, we suggest the building of maritime environmental clusters within Ukraine.

To generalize the international experience, we should note that the following definition is the most relevant to the present-day requirements of economic activities: maritime environmental cluster is a territorial and sectoral voluntary informal association of enterprises and organizations of port operations and related maritime economic industries, which closely cooperate in the process of realization of regional strategy of sustainable development of maritime economic complex with scientific, educational, financial, consulting, and other economic structures, as well as local government agencies with the aim of raising the environmental level of quality of economic operations and competitiveness of all the participants of the association and economic growth of the coastal region.

In the authors' opinion, the environmental maritime clusters that are offered to be built in the coastal area of Ukraine should include environmental infrastructural objects of the industrial port sphere; mineral mining sector; dredging, development of sea hydrocarbon resources; sea recreational activities; burial of waste and dredging waste; as well as financial and scientificeducational institutions whose activities are aimed at environmentalization of maritime economic activities.

\section{Conclusions}

Within the framework of the conducted research, it was proven that the further sustainable development of separate industries and markets of Ukraine is first of all related to the formation of the institutional environment. In the conditions of unstable socialeconomic and environmental situation in the state, research of institutional risks and "traps" will be gaining a special importance. The definition of an institutional risk presupposes that emergence of an institutional trap is not a unique phenomenon for separate economic systems. It has a relatively stable set of risks that come into play automatically in case of disturbance of the balance of growing costs threats prevention for economic agents (transactional and transformational) regarding maintenance of certain property rights transfer and exchange institutions in the market. These risks are as follows: total hostility; limited perspective; unpredictable result. Secondly, the course of post-crisis restoration in Ukraine bears signs of development of the institutional crisis in all domains of public life, in particular, in public administration, as a result of the longterm accumulation of institutional traps in the country's economic system. And, thirdly, removal or prevention of any institutional trap, as well as unblocking of an institutional crisis in Ukraine is possible as a result of institutional reforms based on prediction and modelling of economic agents' behaviour.

The author of the article proves that formation of an institutional system of port industrial areas integrated management in Ukraine needs to be organically interconnected: with the structural reorganization of Ukraine aimed at raising the social-economic and 
economic-environmental efficiency of use of the Black Sea natural resources of high priority for Ukraine; with reformation of the entire system of public administration and local self-government based on integration of efforts of the state and regional government agencies, entrepreneurs, non-governmental organizations, and population.

The following are the most important issues of formation of an efficient institutional system of sustainable development of the facilities used for economic activities in maritime coastal areas of Ukrainian Black Sea region: scientifically grounded organization of relations between territorial and sectoral subjects of environmental management that function within objects of maritime coastal areas (seaside territories - industrial port areas) with the aim of subsequent entry into the European maritime cluster; formation of special institutes and regulatory framework for economic operations in the coastal area of the Black and Azov Seas, which should be based on new legislative acts of Ukraine, which have to be developed within relatively short terms; development and realization of the main directions of formation of the national maritime policy taking into account the priority of the environmental factor and creation of the system of integrated management of the Ukrainian sector of the Black Sea coastal area, which would promote establishment of Ukraine as a maritime state, strengthening of its state independence, improvement of its international authority and affirmation of the ability of Ukraine to comprehensively resolve important social-economic and economical-environmental issues.

\section{References:}

Brennan, J. \& Buchanan, J. (2005) The reasons of rules. Constitutional political economy. SPb.: Ekonomicheskaya shkola [in Russian].

Ostrom, E. (1990) Governing the commons. The Evolution of institutions for collective action. NY: Cambridge University Press.

Knopfel, P. Larue, C. Varon, F. and Malysheva, N. (2010) Analysis and piloting of public policy. Kyiv: Higher Institute of Public Administration in Switzerland, Alerta [in Ukrainan].

Eggertsonn, T. (2005) Imperfect institutions: possibilities and limits of reform. The University of Michigan Press, Michigan, USA.

Lowndes, V. (1996) Varieties of new institutionalism: a critical appraisal. Public Administration, vol. 74, pp. $181-197$.

Kouz, R. (2007) Firm, market and law. Moscow: New publishing house [in Russian].

Nort, N. (1997) a. Institutions, institutional changes and the functioning of the economy. Moscow [in Russian].

Nort, N. (2010) b. Understanding of the process of economic changes. Moscow: Higher School of Economics [in Russian].

Furubotn, E. \& Richter, R. (1991) The new institution economics: a collection of articles from the Journal of institution \& theoretical economics. Tubingen: Mohr.

Gradstein, M. (2008) Institutional Traps and Economic Growth. International Economic Review, vol. 49, No. 3, pp.1043-1066.

Kryizhanovskiy, R.A, Gromova, E.N., \& Galushkina, T.P. (1991) Morskaya ekonomika [Marine economy]. Moskow: Nauka [in Russian].

Gromova, E.N. (2001) Economic and environmental regulation of marine environmental management: public and market methods. Odessa [in Russian].

Burkynskyi, B.V., \& Stepanov, V.M. (2008) Economic and ecological safety of the sea business. Odesa: Phoenix [in Ukrainian].

Weimer, D. L. and Vining, E. R. (1998) Analysis of the policy: concepts and practice. Kyiv: Osnovy [in Ukrainian]. Zhalilo, Y. A. (2009) Theory and practice of forming an effective economic strategy of a state. Kyiv: NISS [in Ukrainian].

The State Fiscal Service of Ukraine (2017) Electronic reporting. Retrieved from: http://sfs.gov.ua/elektronnazvitnist [in Ukrainian].

Fylypenko, A.O., \& Baryshnikova, V. V. (2013) Priorities of the development of the Ukrainian marine economy in the conditions of globalization: an analytical report. The region branch of national institute of strategic research in Odessa, Odessa, Phoenix [in Ukrainian]

ENMC website (2017) European network of marine clusters. Retrieved from: http://enmc.eu/who-we-are 